\section{B A Institute of \\ YK Business Administration \\ 六下 \\ Karachi \\ Leadership and Ideas for Tomorrow}

Business Review

Volume 12 Issue 1 January-June 2017

$1-1-2017$

\title{
The impact of manufacturing activities in the trading partner on imports into Pakistan
}

Aadil Nakhoda

Institute of Business Administration, Karachi, Pakistan

Farooq Pasha

State Bank of Pakistan, I.I.Chundrigar Road, Karachi, Pakistan

Follow this and additional works at: https://ir.iba.edu.pk/businessreview

Part of the Business Administration, Management, and Operations Commons

(c) (1)

This work is licensed under a Creative Commons Attribution 4.0 International License.

\section{Recommended Citation}

Nakhoda, A., \& Pasha, F. (2017). The impact of manufacturing activities in the trading partner on imports into Pakistan. Business Review, 12(1), 20-49. Retrieved from https://doi.org/10.54784/1990-6587.1047

This article is brought to you by iRepository for open access under the Creative Commons Attribution 4.0 License and is available at https://ir.iba.edu.pk/businessreview/vol12/iss1/2. For more information, please contact irepository@iba.edu.pk. 


\section{The impact of manufacturing activities in the trading partner on imports into Pakistan}

\section{Cover Page Footnote}

The opinions, findings and recommendations expressed in this paper are strictly those of the authors. They do not reflect the views of the State Bank of Pakistan. The authors are responsible for any errors or omissions and the State Bank of Pakistan does not take any responsibility for the correctness of the paper. 


\title{
The impact of manufacturing activities in the trading partner on imports into Pakistan
}

\author{
Aadil Nakhoda • Farooq Pasha
}

\begin{abstract}
This paper assesses the volatility of short term real interest rate in Pakistan using Markovs switching model drawing on monthly data from January 1964 to March 2016. This model holds that if the random walk pattern is not visible in the real interest rate series, fluctuation in the series are temporary and the interest rate will be restored around the mean value eventually. The results reveal that the real interest in Pakistan has exhibited high volatility from 1973 onwards and continued to stay in the high variance regime, due to the instability of Pakistans economic conditions and high budget deficits.
\end{abstract}

Keywords Interest Rate - Volatility · Markov switching model.

\section{Introduction}

The size of the manufacturing sector in a country as a proportion of its GDP indicates the importance of value-addition in the manufacturing sector to an economy. A country with a larger manufacturing sector relative to its GDP is likely to be dependent upon its manufacturing sector as a major contributor to economic activities relative to other countries with a smaller manufacturing sector in proportion to their GDP. ${ }^{1}$ In other words, a country with a larger pro-

Aadil Nakhoda

Institute of Business Administration, University Road, Karachi-Pakistan

E-mail: anakhoda@iba.edu.pk

Farooq Pasha

State Bank of Pakistan, I.I.Chundrigar Road, Karachi-Pakistan

Disclaimer: The opinions, findings and recommendations expressed in this paper are strictly those of the authors. They do not reflect the views of the State Bank of Pakistan. The authors are responsible for any errors or omissions and the State Bank of Pakistan does not take any responsibility for the correctness of the paper.

(C)Nakhoda, A. Pasha, F. 2017

1 Certain countries with lower levels of GDP or economic size may report higher values of manufacturing as a percentage of GDP. Democratic Republic of Congo reports the same level as Switzerland and Singapore. Therefore, we include GDP per capita in our regressions to control for the income levels of the trading partners. 
portion of the manufacturing sector relative to its GDP is more likely to be an important supplier of manufactured goods to not only its domestic economy but also to its trading partners. This pattern holds for several countries that report positive trade balances such as Germany, Japan, China and Malaysia. Therefore, the size of the manufacturing sector of the trading partners relative to their GDP is likely to influence the import values into Pakistan. OLS(Ordinary Least Squares) and GLS (Generalized Least Squares) methods estimate the impact of the size of the manufacturing sector relative to the GDP of the trading partner on the imports into Pakistan. The regressions include several control variables that not only account for the size of the services sector relative to GDP but also the export-orientation, the level of productivity, location from the core of global economic activities and the gravity variables that define the distance and similarities between Pakistan and its trading partners.

Imports embody foreign technology and may lead to higher economic growth if complemented well with domestic inputs. Countries with larger manufacturing sectors as a proportion of their GDP are likely to have greater comparative advantage in the production of manufactured goods. Although imports can be beneficial, our major concern is the fact that Pakistan may have become overwhelmingly dependent on the imports of processed goods as the total imports increased at approximately 11 percent per annum between 1998 and 2013.

The imports of primary goods that are converted into processed goods within Pakistan may benefit the economy, the imports of processed goods can be detrimental to the economy if it substitutes away the value addition of the manufacturing sector within Pakistan. For instance, if Pakistan is to import processed products such that the consumers may become increasingly dependent upon the imports and substitute demand away from domestic producers, it will reduce the value of domestic production within Pakistan. On the other hand, Pakistan can benefit through the imports of primary goods if they require further value addition in Pakistan such that most of the value addition in the final product is domestic rather than foreign. ${ }^{2}$

The imports are classified as food and beverage products, industrial supplies, fuel and lubricants, capital goods, transportation equipment and consumer goods. The first three categories are disaggregated into primary and processed goods as they constitute a significant proportion of imports into Pakistan and are likely to be produced within Pakistan as well. However, due to the nature of production in terms of capital and knowledge intensity, the production of capital goods and transportation equipment is unlikely to constitute a large proportion of the domestic manufacturing sector in Pakistan. ${ }^{3}$

Shrinking industrial output accompanied by a reduction in the gross fixed

\footnotetext{
2 Although both primary and processed goods can involve different production stages within each classification, it is likely that the imports of primary goods will involve manufacturing activities in Pakistan that convert it into processed goods. However, depending upon the stages of production, processed goods may or may not require manufacturing activities in Pakistan.

3 According to the Census of Manufacturing Industries (2005-2006), food and beverage industry constitutes $20 \%$ of the total value of production, petroleum industry constitutes $10 \%$ and transportation equipment industry constitutes $6 \%$. Industrial supplies are intermediate goods used in production across all sectors of the manufacturing industry.
}

Business Review: (2017) 12(1):20-49 
capital formation has reduced the ability of Pakistan to produce processed goods and increased its dependency on imported processed goods. Another drawback of the dependency on imported processed products is that as a lower middle income country, the industries within Pakistan may become entrenched in a vicious cycle that not only depends on the imports from countries with larger manufacturing sectors but may only produce low-valued products domestically. It is imperative that Pakistan focuses on the imports of primary products, converting them into processed goods domestically for exports as well as for local sales. Our results suggest that Pakistan is likely to import goods from countries with larger manufacturing sectors, particularly the processed products. ${ }^{4}$

This study will help determine whether imports into Pakistan are likely to be influenced by the size of the manufacturing sector in the trading partners relative to their GDP and whether the pattern can be differentiated between primary and processed goods for food products, industrial supplies and fuel and lubricants. We also control for the size of the services sector relative to GDP in the trading partner as services such as transportation and communication, financial services, information and technology, as well as wholesale, retail and storage provide the necessary impetus to manufacturing activities.

The manufacturing sector in several countries is heavily dependent upon the services sector. Countries that produce better quality high value added products may require a complementary services sector and have higher contributions from both manufacturing and services sector to GDP, enhancing the quality of their imports and consequently the import value received by Pakistan. ${ }^{5}$ On the other hand, imports can be more dependent upon the level of manufacturing activities and less dependent upon the provision of services, particularly when services in the trading partners are less formalized and not complementary to manufacturing activities. We expect a positive impact of the size of the manufacturing sector relative to GDP on the imports into Pakistan but a negative impact of the size of the services sector to GDP on the imports into Pakistan if the production of goods imported require lower levels of complementary services. Further, we expect processed products to have a greater dependency on the size of the manufacturing sector relative to GDP in the trading partners than primary products.

We discuss relevant literature in section 2 followed by a discussion on the theoretical framework that connects the size of the manufacturing sector in the trading partners relative to their GDP and the pattern of imports into Pakistan in section 3. We define the data and the econometric specification in section 4

\footnotetext{
4 Imports doubled between 2003 and 2005, the period the growth in large-scale manufacturing was at its peak. On the other hand, imports fell in 2009, the year the large-scale manufacturing reported negative growth rates. Therefore, an increase in manufacturing activities may demand imports but the nature of imports is likely to be different. For instance, demand for capital goods and primary products is likely to be accompanied by the growth in manufacturing activities.

5 We consider the manufacturing sectors and the services sector at the aggregate-level. We expect higher contributions from both manufacturing and services sector to GDP in developed and advanced countries. A positive correlation between imports and the size of manufacturing sector as well the services sector relative to GDP suggests a complementary relationship between both sectors. Therefore, we control for the size of the services sector relative to GDP in our regressions.
} 
and present the empirical framework and the results of the regressions in section 5 . We conclude in section 6 .

\section{Literature review}

Developed countries experienced deindustrialization as the contribution of the manufacturing sector to total employment shifted away from the manufacturing sector towards the services sector. Krugman and Lawrence (1993) argue that exposure to international trade through increasing imports is not the reason for the deindustrialization of the US economy beginning in the 1950s. They refute the misconception that imports eroded the manufacturing base of the US and created a loss of high paying jobs. They contend that domestic issues such as shifting of domestic expenditure from manufactured goods to services resulted in the shrinking of the manufacturing base as consumers with their rising incomes demanded better services.

Rowthorn and Ramaswamy (1997) suggest that deindustrialization in the developed world is a natural phenomenon as countries move from manufacturing sector to services sector. However, such a shift is likely to be a consequence of productivity increases in the manufacturing sector as it is defined as technologically progressive. In essence, labor shifts from manufacturing to services due to the labor-saving nature of the advances in technology in manufacturing, with workers moving to services sector as they face unemployment in the manufacturing sector. The authors also mention that the North-South trade has had a minimal impact on the deindustrialization of the developed countries. However, we should expect developing countries to experience industrialization before they divert their employment to the services sector, following the trend that had once been set in the developed and advanced countries.

Such is not the case for Pakistan as Hamid and Khan (2015) discuss the advent of premature industrialization in Pakistan. The shrinking of the manufacturing sector from 2007 onwards along with the increasing domestic issues has impacted the industrialization of the country. Our paper shows that Pakistani imports are positively influenced by the size of the manufacturing sector in the trading partners. As Hamid and Khan (2015) emphasize that premature industrialization may not be a temporary problem. It is further exacerbated as imports into Pakistan are dependent upon the size of the manufacturing sector of the trading partners. Rasiah and Nazeer (2015) suggest that lack of an industrial policy that emphasizes on technological upgrading and proper exchange rate management coupled with poor tariff and tax policies have led to stagnation in low-value added manufacturing activities. Therefore, instead of catching up with the more developed trading partners and reducing the demand for imports of processed products, we expect an increase in demand for all product categories imported into Pakistan.

In addition, Choudhary and Pasha (2015) consider the negative impact of the lack of industrialization in Pakistan as they indicate that deindustrialization in Pakistan was accompanied by the growth of low-valued traditional services sector. Rasiah and Nazeer (2015) point out the impact of premature deindustri-

Business Review: (2017) 12(1):20-49 
alization within a country on its economic growth as it not only fails to benefit from growth-enhancing benefits of manufacturing but also experiences a shift in employment from the manufacturing sector towards the informal low-valued traditional services sector. This suggests that the deindustrialization experience for Pakistan was different from the experience of developed economies. The authors further suggest that the lack of industrialization in Pakistan is likely to worsen the balance-of-payments for Pakistan as it increases the current account deficit. In essence, our study emphasizes on this point as it considers the impact of the size of the manufacturing sector relative to GDP of the trading partners on the increasing import demand into Pakistan.

Rodrik (2016) puts forward a plausible explanation for the demand for imports into a country like Pakistan that is experiencing premature industrialization and the manufacturing activities in the trading partners. With the increase in globalization, countries without a strong comparative advantage are likely to become net importers and their imports will be influenced by the size of the manufacturing sector relative to the GDP in the trading partners. Countries with larger manufacturing sectors are likely to become the core of global manufacturing activities and their efficiency in production will determine their quality of output and the price level of the manufactured goods. Therefore, determining the relationship between imports and the size of the manufacturing sector relative to GDP has an important policy implication for countries with relatively weaker comparative advantage in manufacturing activities such as Pakistan.

Imports can benefit the economy if there is a viable domestic manufacturing sector that can convert goods from raw and primary form into processed and final products through different stages of production. As imports may embody superior technology available in the trading partners, they can benefit the producers in the importing country. Amiti and Konings (2007), using plant-level data on Indonesian firms, suggest that imported inputs increases the productivity levels of importers as well of the non-importers significantly. Kugler and Verhoogen (2009), borrowing plant-level data from Colombia, present a set of stylized facts that differentiates imported inputs from domestically produced inputs incorporated into production. The authors state that producers who import their inputs are likely to be more productive than their non-importing counterparts, imported inputs are likely to be of more superior quality than the domestically available inputs and that importers are likely to pay higher prices for the same inputs otherwise available domestically.

Considering data on Indian imports, Goldberg et al (2009) determine that an increase in the variety of imports lowers the import price index, suggesting that importers are likely to obtain cheaper varieties of inputs. ${ }^{6}$ The authors also find that inputs are more likely to be sourced from developed countries. Considering the case for Pakistan, imported inputs may have benefitted local producers by improving their productivity as well as introduced cheaper varieties of inputs into the economy as producers maximize their individual profits.

However, the recent declining trend in manufacturing activity suggests that

6 The similarity of the Pakistani importers is likely to be closer, in terms of their preferences, to the Indian importers than to the Colombian importers. Therefore, Pakistani importers may have a preference for cheaper varieties as well. 
such benefits may not have been actualized at the aggregate level. We believe that the rising imports may have been a consequence of the dependence on imports from countries with larger manufacturing sectors, as such imports substitute the domestic inputs either due to lack of availability or poorer quality of the latter. Therefore, keeping in view the differences between foreign and domestic inputs in production, we further classify imports into primary and processed goods.

The purpose of this study is to determine the influence of the size of the manufacturing sector on the import values reported by Pakistan. In the survey of literature on this topic, it is suggested that imports from countries with a comparative advantage in the manufacturing sector are not only likely to be cheaper than domestic varieties, they can also be of higher quality than the domestic inputs, include differentiated variety of inputs that allow firms to diversify as well as incorporate learning effects and spill-over effects, that may increase the productivity of importing firms. Our study considers whether the role of the manufacturing sector differs across product categories as well as across product types, primary and processed, within the broad economic categories. We contribute to literature by presenting a case of a developing country that experiences a decline in the size of its manufacturing sector but exhibits a positive influence of the size of the manufacturing sector on its imports from its trading partners.

\section{Theoretical framework}

Dornbusch et al (1977) Eaton and Kortum (2001) and Hummels et al (2001) provide the basis for the theoretical framework of this research. These studies incorporate the Ricardian model, which explains that trading patterns across countries differ due to differences in technologies within each trading partner. On the demand-side we assume identical tastes such that demand is homothetic across all trading partners. We also assume that consumers will search the world markets for their goods and purchase the bundle of goods available at the lowest price (after considering the transportation costs). ${ }^{7}$ Hence, all consumers will purchase a bundle of goods that are produced at Home and in Foreign based on the respective comparative advantage of Home and Foreign in the manufacturing sector.

On the supply-side, we assume that every country has access to technology that improves production efficiencies and will determine its comparative advantage in the production of goods. ${ }^{8} \mathrm{~A}$ trading partner will report comparative

\footnotetext{
7 However, trading partners with a comparative advantage in the production of their goods can also provide inputs of higher quality and differentiated varieties at a lower price as discussed in the previous section.

8 The comparative advantage differs from absolute advantage, as the latter is gauged by the size of the economy. The absolute advantage of a trading partner is gauged by the respective size of its economy as a relatively larger economy than the other trading partners may produce a larger bundle of products in all economic sectors. On the other hand, a country with a greater comparative advantage in the manufacturing sector is likely to produce its bundle of manufacturing goods more efficiently. Therefore, a trading partner with comparative advan-
} 
advantage in manufacturing activities if the manufacturing sector constitutes a larger share of the total economy. This indicates that technological advancement in a trading partner that is available to all sectors of the economy is likely to be more concentrated within the manufacturing sector. It will likely export a certain proportion of its manufactured output as production efficiencies will be more than sufficient than that required for domestic consumption of manufactured products. However, trade costs may diminish the benefits of comparative advantage and there will always be a proportion of goods produced that are consumed domestically in Home and Foreign. Therefore, trading patterns are likely to be determined by the relative size of the manufacturing sector to GDP rather than its absolute size, as a country with a larger manufacturing sector relative to GDP will be required to export its excess production. In our discussion below, we define Home as a less-developed country that imports goods from its more developed trading partner, defined as Foreign. Further, Foreign also has a comparative advantage in its manufacturing sector.

Dornbusch et al (1977) consider the competitive margin of production of goods across countries. International trade flow is dependent upon technological differences between countries as it dictates the comparative advantage of one trading partner over the other. ${ }^{9}$ For instance, Home will produce lesser goods domestically if it experiences a loss in its comparative advantage due to lower efficiency levels in production relative to Foreign. This reduction in domestic production will lead to a trade deficit in Home. In order to offset this deficit, the wages must fall in Home.

However, both countries are only likely to trade if it improves their welfare, the real wages in terms of goods purchased must increase. The fall in relative wages in Home must fall short of the fall in relative unit labor requirements in Foreign. Therefore, the wages in Foreign are likely to increase as the production efficiencies improve. In essence, the increase in productive capabilities of Foreign, as determined by the size of its manufacturing sector relative to GDP, is likely to be accompanied by an increase in the GDP per capita levels. The size of the manufacturing sector relative to the GDP and the GDP per capita levels must have a positive relationship with the import levels into Home. ${ }^{10}$ This indicates an overall improvement in welfare as production of manufacturing goods is shifted to countries with a comparative advantage in its production. This is consistent with the plausible explanation on the premature deindustrialization in poorer developing countries as indicated by Rodrik (2016) and its increasing reliance on imports from trading partners with a larger manufacturing sector relative to GDP.

\footnotetext{
tage in its manufacturing sector is likely to export its manufacturing products as it produces more than its consumption relative to other economies.

9 The technological differences are determined by the relative unit labor requirements to produce one unit of a good in each country, Home and Foreign.

10 Krugman and Venables (1995) discuss the importance of core countries with stronger manufacturing sectors and periphery countries which are likely to import products from the core countries. With falling transportation costs, this may likely to lead to further industrialization of the core countries and deindustrialization of the periphery countries. We have included a variable that accounts for the remoteness of the trading partner based on the distance to core countries in our econometric specification.
} 
Eaton and Kortum (2001) consider whether the geography, in terms of the distance between the two trading partners, and technology compete in setting the comparative advantage between Home and Foreign. If Home has a smaller manufacturing base relative to its GDP than Foreign, it is likely that production will shift to Foreign as geographic barriers between Home and Foreign diminish. This shift in production occurs as technology cannot be easily transferred from the high-wage Foreign country to the low-wage Home country. As we assume Home to be in its earlier stages of development and limitations in capital-movement between countries exist, it is likely to rely on the imports of goods from its trading partners rather than investments in foreign capital. Therefore, the differences in comparative advantage between Home and Foreign will promote the imports into Home from Foreign and widen the trade deficit in Home.

Hummels et al (2001) incorporate the possibility of vertical specialization in production of goods into the Dornbusch, Fischer and Samuelson model. Vertical specialization occurs when Home may import intermediary goods which are further processed and converted into finished goods for domestic consumption and exports. For instance, the Home country may import inputs in its primary form and process it into finished form. The differences in production technology between Home and Foreign may determine this pattern of trade as Home may vertically specialize in certain stages of output in which it retains comparative advantage. For instance, several developing countries with lower levels of wages import cotton yarn and cotton fabric, which are capital intensive, to convert into finished textile labor-intensive products using their comparative advantage in labor. We expect low-wage manufacturing activities in Pakistan, which could allow vertical specialization that involves labor-intensive industries.

Although, imports of primary goods may benefit the local manufacturing sector as they are converted into processed goods, the increasing imports of processed goods may substitute away from domestic production into foreign production, particularly if the trading partners have large manufacturing sectors relative to GDP that have comparative advantage in several different stages of production.

In this paper, we consider the impact of the size of the manufacturing sector relative to GDP on the import values into Pakistan. If we observe positive values, it suggests that Pakistan is likely to import from countries with larger manufacturing sectors relative to GDP and that the manufacturing activities in the trading partner are likely to be more efficient. On the other hand, if we observe negative values, we would expect lower manufacturing activities in the trading partner and less dependence of goods on manufacturing activities. If primary products and processed products of the same category are imported from countries with a larger manufacturing sector relative to GDP, Pakistan must involve itself in the production chain through vertical specialization by offering low-wage manufacturing activities that are not common in high-wage countries with developed manufacturing sectors, ensuring the expansion of manufacturing activities in Pakistan. This will help Pakistan reduce its trade balance. On the other hand, the negative influence of the size of manufacturing sector relative to GDP on the imports of primary products but a positive influence on the 
imports of processed products may suggest that conversion of primary products into processed products is likely to happen in different countries, as the former involves less manufacturing activities than the latter.

One of the major concerns is that variables accounting for the size of the manufacturing and services sector, imports into Pakistan and economic development are likely to be skewed to the right. Our theoretical model implies that not only is manufacturing activity likely to be concentrated within a few countries, majority of the imports into Pakistan are likely to originate from a handful of countries. Therefore, we have transformed the continuous variables into their respective natural logarithms and considered a double-log functional form. On the other hand, we have also included dummy variables accounting for the contiguity with Pakistan, common official language shared with Pakistan, common colonizer post 1945, and colonial linkages. The inclusion of the variables is consistent with the gravity model.

\section{Data}

We borrow our data on the value of imports into Pakistan from all trading partners from the United Nations COMTRADE Database. In Appendix A, we list the independent variables and their sources. We consider the time period from 1998 to 2013. We classify our products according to the Broad Economic Categories as published by the United Nations.

Within each of the categories, the commodities have been classified as either primary or processed based on the contribution of the value transformation. If the value is minimal, the product is classified as primary. This includes products obtained from farming, fishing, forestry, hunting and mining and quarrying. On the other hand, if much of the value of a product is attributed to the manufacturing process, the product is classified as processed instead of primary. Examples of primary goods include raw fish, meat, and crude oil and examples of processed goods include canned and packaged food and petroleum.

\subsection{Econometric Specifications}

The purpose of our study is to determine the relationship between the imports into Pakistan and the manufacturing activity as well as the depth of the services sector in the trading partners of Pakistan. We conduct an OLS regression using the following equation:

$$
\text { lnImpValue }_{i t}=\beta_{0}+\beta_{1} \text { lnManu }_{i t}+\beta_{2} \operatorname{lnSer}_{i t}+\beta_{3} \text { CountChar }_{i t}+\alpha_{t}+\epsilon_{i t}
$$

where $\operatorname{lnImpValue}{ }_{i t}$ is the value of imports into Pakistan, $\operatorname{lnManu_{it}}$ is the value added in the manufacturing sector as a percentage of GDP in the trading partner, $\operatorname{lnServ} v_{i t}$ is the valued added in the services sector as a percentage of GDP in the partner, CountChar ${ }_{i t}$ are the characteristics of the trading partner, $\alpha_{t}$ is time fixed effects and $\varepsilon_{i t}$ is the error term, normalized at $(0,1)$. i denotes 
importing partner and $t$ denotes year. The country characteristics include variables that determine the level of GDP per capita of the trading partner, the proportion of goods destined for lower middle income countries, exports as a percentage of GDP, weighted average tariffs imposed by Pakistan on the imports of goods from the trading partner and the remoteness, defined as proximity to core countries.

The GDP per capita of the trading partner determines the level of economic development within a trading partner and the level of comparative advantage in the importing country, with higher levels reported for more advanced and developed countries. This may control for higher efficiency levels in the trading partners that can otherwise magnify the impact of the size of the manufacturing sector on imports into Pakistan. As Pakistan is a lower middle income country, we control for the percentage of goods that are exported to lower middle income countries similar to Pakistan. This ensures that the trading partners produce goods that are likely to be traded with lower middle income countries and less redundant for a country that is as technologically advanced as Pakistan. In essence, including the variables on GDP per capita and the percentage of goods exported to lower middle income countries not only controls for the composition of the export basket of the trading partners but also for the type of goods that are primarily exported by the trading partners. This is consistent with the discussion in Hausmann et al (2007).

Exports as a percentage of GDP indicates whether a country produces primarily for the export market rather than for the domestic economy. A negative impact suggests that Pakistan is likely to import from countries where a larger percentage of goods produced are consumed domestically. Hummels and Klenow (2005) consider the variety and quality of a country's exports. They find that larger countries, as indicated by the size of their domestic economy in our model, are more likely to export greater variety and better quality resulting in higher exports. This is consistent with our model as countries that report higher values of exports as a percentage of GDP tend to have lower levels of domestic consumption and will export lesser varieties and lower quality of output.

Tariffs are imposed on products to either discourage their imports or generate revenue through customs duty but lead to a distortion in the prices of imports. The inclusion of weighted average tariff rates helps to determine whether price distortions influence imports into Pakistan.

The remoteness index measures the distance of the trading partner from the core of the world economy and ensures that our model is consistent to Krugman and Venables (1995), who discuss the industrialization of the core economies and deindustrialization of the economies in the periphery. ${ }^{11}$ Higher remoteness index indicates greater costs of trading for the country as it has an unfavorable location. Countries closer to the core are likely to produce a greater number of varieties and report higher values of trade.

Finally, we include the variables on the gravity equation in order to control for not only the proximity of the trading partner to Pakistan but also charac-

11 Remoteness is defined by UNCTAD in its criteria for identification of least developed countries as it calculates the weighted distance to its nearest trading partners accounting for 50 percent of the world trade and is adjusted for if the trading partner is landlocked.

Business Review: (2017) 12(1):20-49 
teristics that would indicate a closer trading relationship between the trading partner and Pakistan. The weighted tariff rates, the remoteness index and the variables from the gravity model control for the barriers to trade in order to increase consistency with our theoretical model and the study by Eaton and Kortum (2001) that emphasizes on the relationship between geography and trade.

Although our primary focus is on the size of the manufacturing sector relative to GDP in the trading partners, we include the size of the services sector relative to GDP. In our literature review, we have discussed the importance of the expanding services sector as several countries have transformed from industrialized countries towards service-oriented economies, suggesting a complementary relationship between the two sectors. On the other hand, countries that have experienced premature deindustrialization have also experienced growth in their services sector. Therefore, we have controlled for the size of the services sector relative to GDP, while excluding the size of the natural resources sector that includes agriculture and mining and quarrying, relative to GDP.

We expect a positive coefficient for the GDP per capita as several of the trading partners of Pakistan are developed and advanced countries. We expect a positive coefficient for proportion of goods destined for lower middle income countries as countries that produce goods for such destinations are more likely to trade with Pakistan. On the other hand, we expect a negative relationship between import value and the other variables listed. Countries with higher export as a percentage of GDP are typically countries with smaller domestic economies and may produce less in absolute terms. ${ }^{12}$ We also include variables that account for the gravity model, such as distance between Pakistan and its trading partner, dummy variables on whether Pakistan shares a border, common official language, colonial link and common colonizer post 1945. We expect a positive relationship between the dummy variables and the import value but a negative relationship between distance and the import value.

We conduct a generalized least squares (GLS) estimation in order to account for heteroscedasticity and autocorrelation such that the GLS is more efficient than the OLS as it is likely to have smaller standard errors and larger t-statistics. As Pakistan trades significantly more with a few countries, it is likely that there will be heteroscedasticity in the error term. Similarly, errors may not be independent across observations as residual in one period is likely to be carried across to the next period. These issues in estimations may render the OLS inefficient. We have introduced the GLS estimations as a sensitivity analysis in order to determine whether the results are similar in the presence of heteroscedasticity and autocorrelation in the error terms.

\footnotetext{
12 Exports as a percentage of GDP for China in 2014 was $22.4 \%$ and for the US was $13.4 \%$, while the highest was report for Hong Kong and Luxembourg at over $200 \%$. There are several Central and Eastern European countries and African countries with higher levels of exports as a percentage of GDP, which are likely to report lower values of trade with Pakistan. Several countries such as the oil-rich Middle Eastern countries have abundant natural resources and smaller values for the manufacturing sector relative to GDP.
} 


\section{Results}

In figure 1, we plot the total imports into Pakistan from 1998 to 2013. The imports increased from US dollar 11 billion in 2002 to US dollar 42 billion in 2008. This sharp increase in imports in six years suggests the rising importance of imported products in the economy of Pakistan. In figure 2, we present the

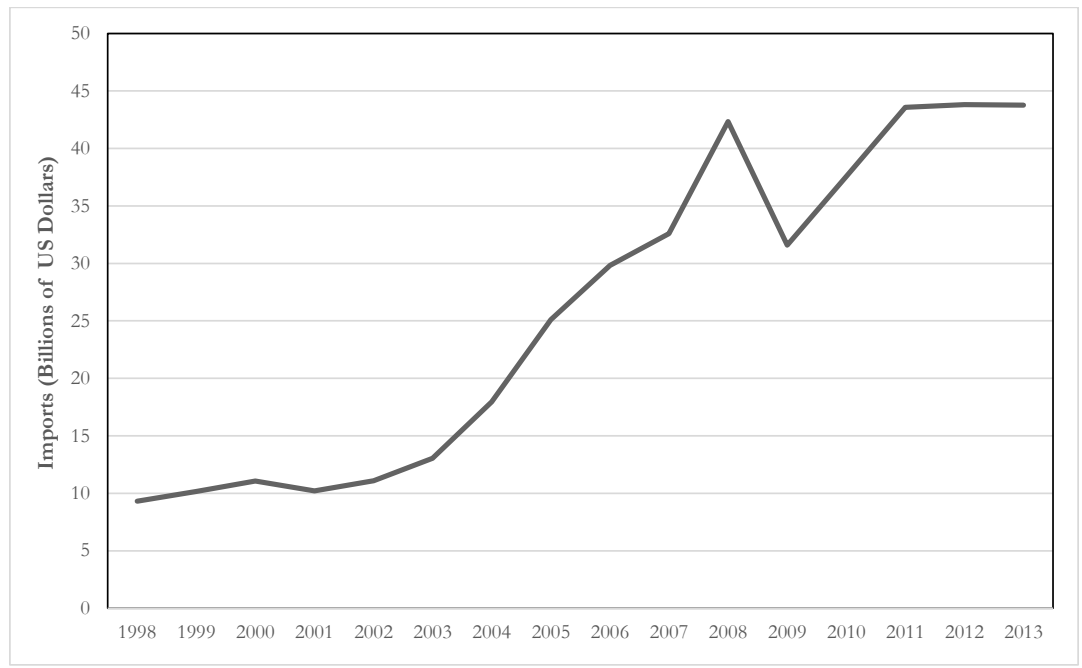

Fig. 1: Total imports into Pakistan from all trading partners

proportion of total imports into Pakistan by broad economic categories. This suggests the importance of each category imported into Pakistan. We find that the industrial supplies and fuel and lubricants contribute to the highest proportion in total imports into Pakistan. Between 2000 and 2005, a large proportion of imports was dominated by industrial supplies. Further, there was increase in the proportion of imports in capital goods. However, since then we have observed a downward trend in the proportion of imports in capital goods. This trend coincides with the growth in domestic manufacturing activity. Similarly, we observe a continuous downward trend in the proportion of imports of food and beverages. The total contribution of transportation equipment and consumer goods in the total imports into Pakistan has been relatively small.

In figure 3, we plot the imports of primary products of food and beverages, industrial supplies and fuels and lubricants. As primary products are likely to be in raw material form, the conversion of primary products to processed products is likely to take place within the importing country and will be dependent upon the size of the manufacturing sector. The demand for primary products is likely to fall as the manufacturing sector shrinks. We observe a decline in the contribution of imports of primary products after 2009, which suggests that Pakistan started importing processed products rather than primary products.

In figure 4, we plot the correlation graphs between the imports into Pakistan

Business Review: (2017) 12(1):20-49 


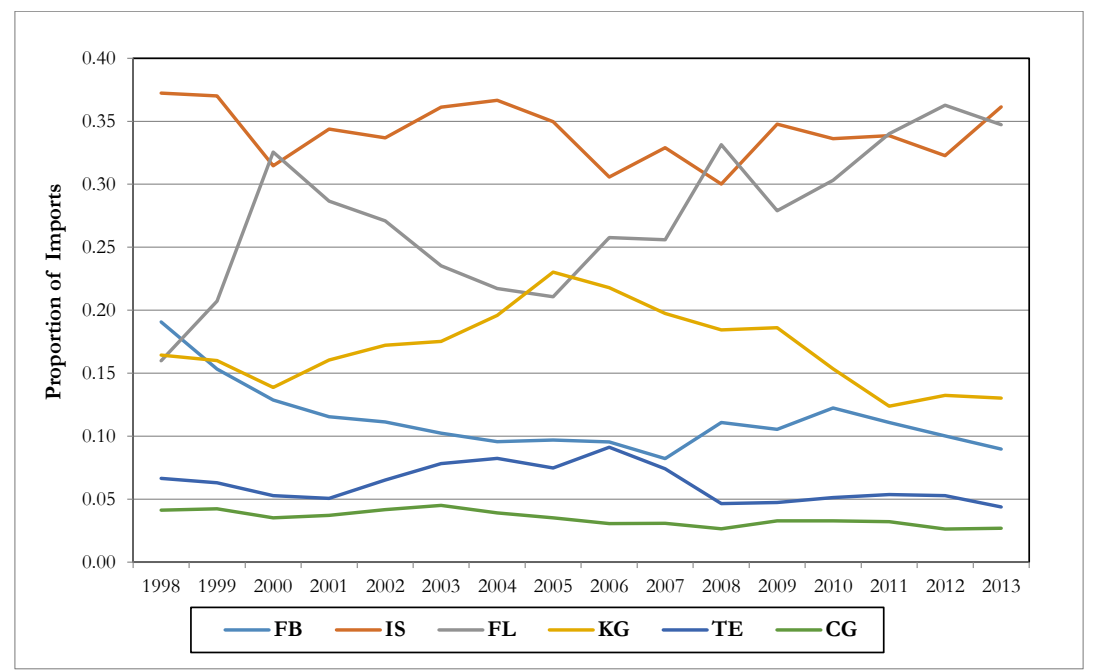

Fig. 2: Proportion of total imports by broad economic category

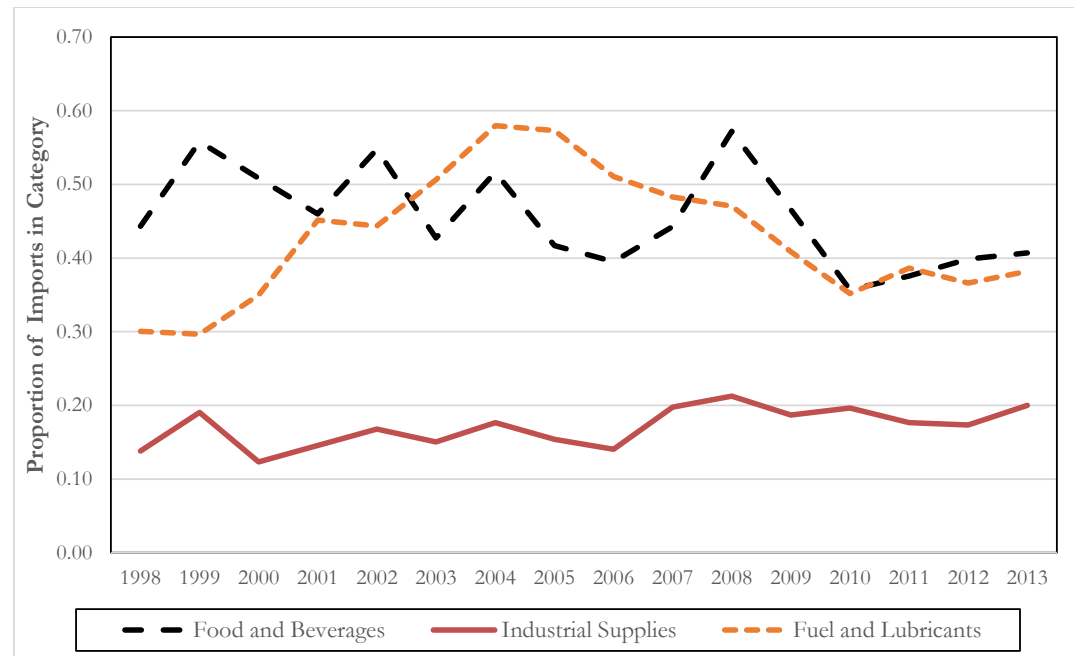

Fig. 3: Proportion of imports of primary products for selected categories

from its trading partners and the size of their manufacturing sector relative to GDP for the year 2013. We observe positive correlations for all categories and their products, except fuel and lubricants and its primary and processed products. Therefore, we expect manufacturing activities in our trading partners to increase the imports into Pakistan in all categories except fuel and lubricants. In figure 5, we plot similar graphs for the relation between imports into Pakistan from its trading partners and the size of their services sector relative to GDP for the year 2013. In figure 5, we observe a similar trend as in figure 4. However, the strength of the correlation is much weaker than in figure 4. 


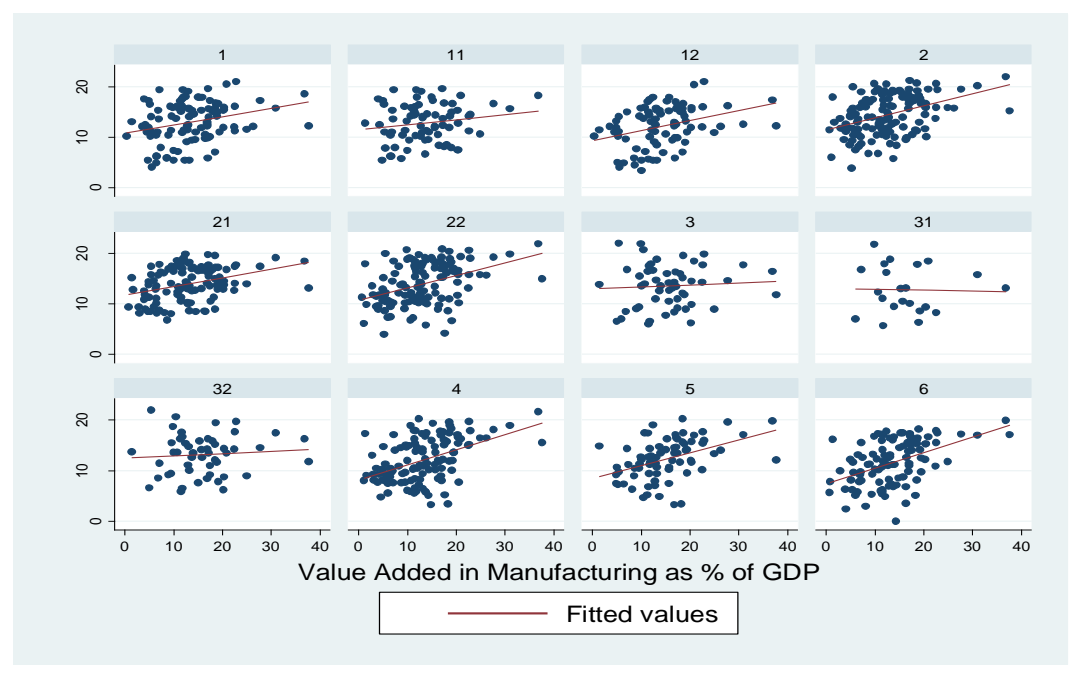

Fig. 4: Correlation between imports from trading partners and contribution of manufacturing to GDP by BEC products in 2013

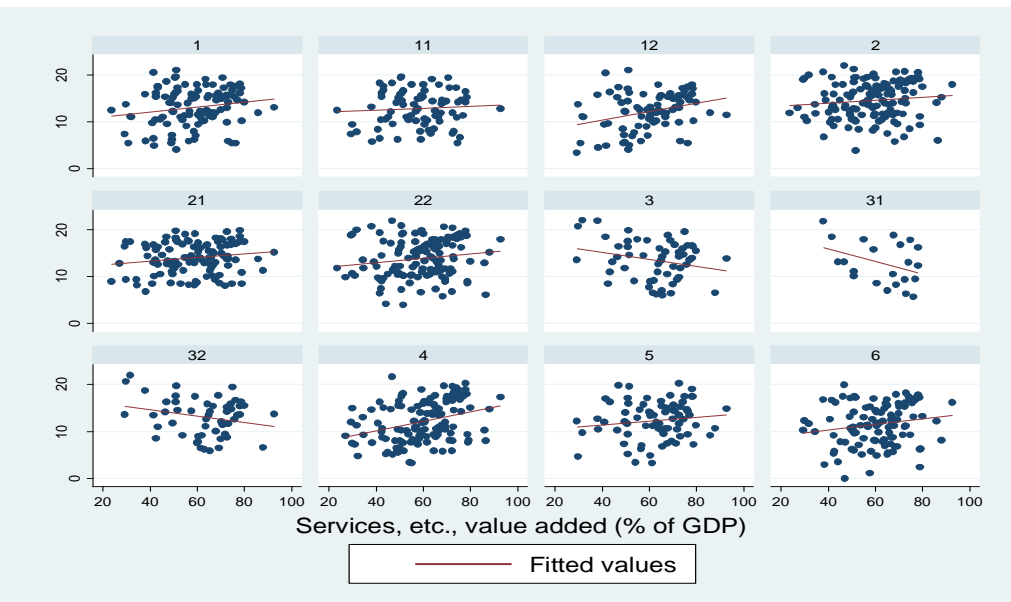

Fig. 5: Correlation between imports from trading partners and contribution of services sector to GDP by BEC products in 2013

In figures 6 and 7, we calculate the trade weighted contribution of the manufacturing and the services sectors of the trading partners respectively for each category of goods and the primary and processed products of food and beverages, industrial supplies and fuel and lubricants. ${ }^{13} \mathrm{~A}$ higher value suggests that

\footnotetext{
13 The trade weighted index is calculated as the sum of the multiplication of the proportion contributed in total imports by a trading partner and the size of the manufacturing sector or the services sector relative to the GDP across all trading partners. Therefore, a higher index number indicates that Pakistan is likely to import the product from countries with a larger manufacturing sector relative to GDP.
}

Business Review: (2017) 12(1):20-49 


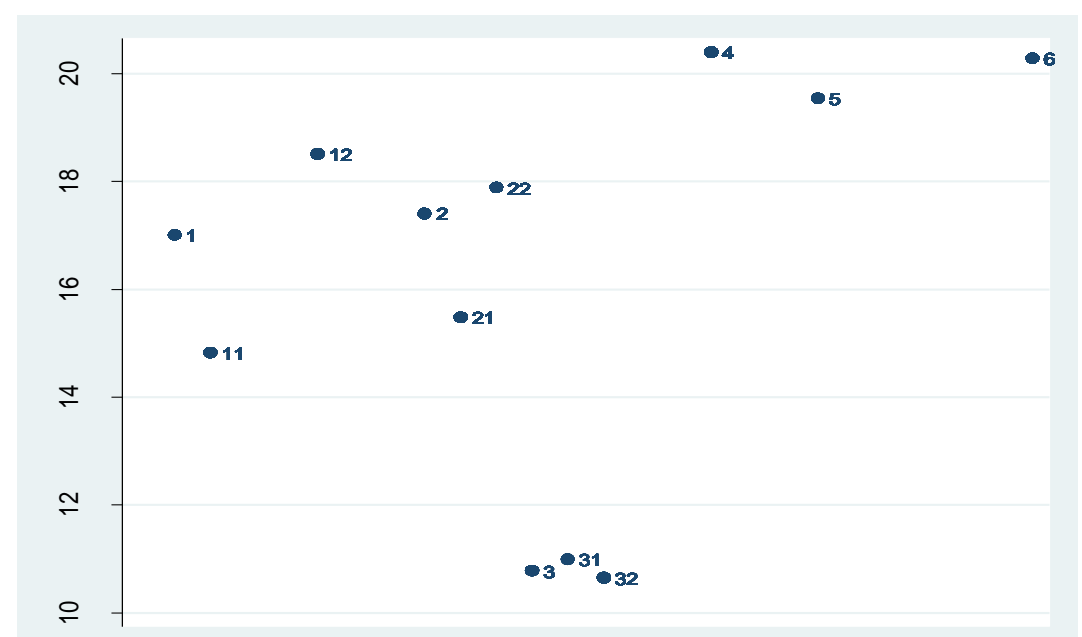

Fig. 6: Trade weighted contribution of manufacturing sector to GDP at product-level in 2013

a good is dependent upon the manufacturing or services activities in the trading partner as it is sourced from countries with larger manufacturing or services activities relative to GDP. Therefore, as expected, fuel and lubricants report the lowest values, while capital goods, transportation equipment and consumer goods, which are likely to be dependent upon manufacturing and services activities for their production report higher values. The processed products of food and beverages and of industrial supplies report higher index values for the manufacturing sector but lower values for the services sector than the primary products.

In Appendix $\mathrm{C}$ we plot the annual values of the trade weighted indices for the manufacturing and the services sector for each category respectively from 1998 to 2013. Fuels and lubricants report the lowest values across the time period. Similarly, food and beverages and industrial supplies have also reported lower values for both indices than capital goods, transportation equipment and consumer goods across the time period. We also find that the index value for the trade weighted manufacturing sectors shows an increasing trend from 1998 to 2013 for capital goods, transportation equipment and consumer goods but has remained almost constant for food and beverages, industrial supplies and fuel and lubricants. This suggests that capital goods, transportation equipment and consumer goods are more likely to be imported into Pakistan from countries with larger manufacturing sectors in 2013 than they were in 1998 and indicates the increasing dependence of imports on manufacturing activities in the trading partner. The increasing trend in the index of these goods is more prominent for the manufacturing sector than the services sector.

In table 1, we report the results of our regressions of manufacturing and services as a percentage of GDP on the import value for the list of products classified by BEC. ${ }^{14}$ We find positive values, significant at $1 \%$ level, for the

\footnotetext{
14 In order save space we abbreviate each product classification. The reference to the abbreviations is listed in Appendix B
} 
The impact of manufacturing activities...

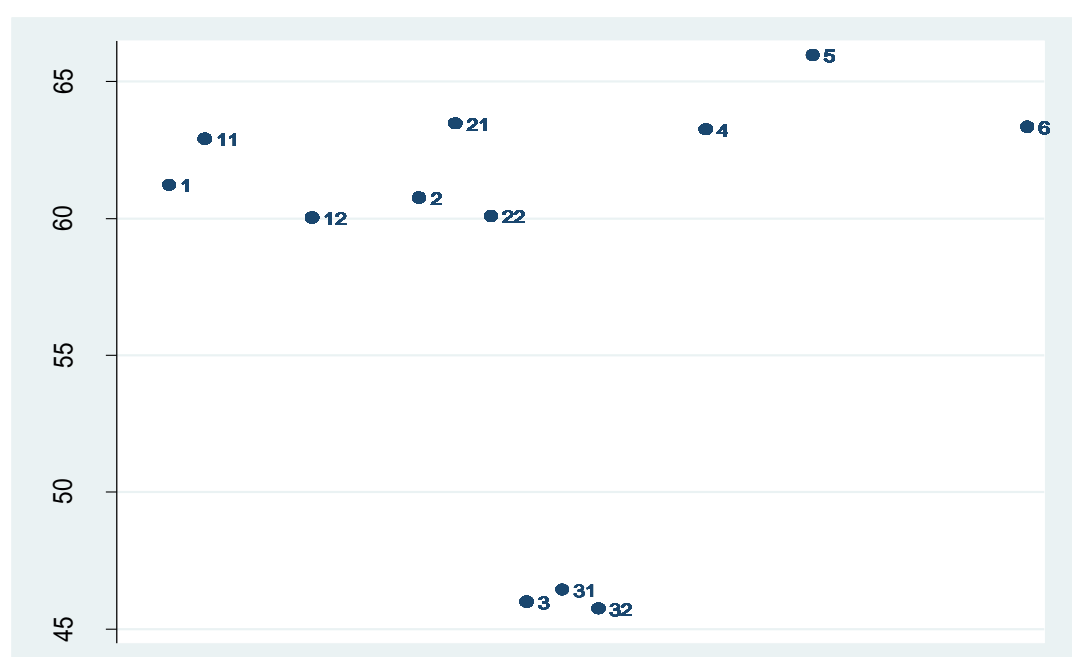

Fig. 7: Trade weighted contribution of services sector to GDP at product-level in 2013

Table 1: OLS regressions of manufacturing and services on import value without control variables for listed broad economic categories

\begin{tabular}{l|llllll}
\hline \multirow{3}{*}{ Import Value } & 1 & 2 & 3 & 4 & 5 & 6 \\
& FB & IS & FL & KG & TE & CG \\
\hline \multirow{3}{*}{ G\% of } & $1.61^{* * *}$ & $2.04^{* * *}$ & -0.24 & $2.56^{* * *}$ & $2.24^{* * *}$ & $2.51^{* * *}$ \\
& & & & & & \\
S\% of GDP(ln) & $(0.137)$ & $(0.111)$ & $(-0.279)$ & $(0.137)$ & $(0.183)$ & $(0.161)$ \\
& $0.90^{* * *}$ & $1.49^{* * *}$ & $-3.1^{* * *}$ & $3.40^{* * *}$ & $2.96^{* * *}$ & $2.97^{* * *}$ \\
Constant & $(0.291)$ & $(0.253)$ & $(-0.619)$ & $(0.325)$ & $(0.365)$ & $(0.338)$ \\
& $5.60^{* * *}$ & $3.31^{* * *}$ & $26.7^{* * *}$ & $-7.3^{* * *}$ & $-5.4^{* * *}$ & $-6.5^{* * *}$ \\
& $(1.11)$ & $(1.02)$ & $(-2.89)$ & $(-1.32)$ & $(-1.45)$ & $(-1.34)$ \\
\hline Obs & & & & & & \\
$R^{2}$ & 1,462 & 2,136 & 727 & 1,731 & 1,171 & 1,519 \\
\hline
\end{tabular}

Note: Robust standard errors in parentheses. Abbreviations for the product classifications are listed in Appendix B.

*** $p<0.01,{ }^{* *} p<0.05,{ }^{*} p<0.1$

coefficient of manufacturing as a percentage of GDP across all products except fuel and lubricants. We observe a negative relationship, albeit insignificant, between manufacturing as a percentage of GDP for fuel and lubricants. We report positive values, significant at $1 \%$ level, for the coefficient of services as a percentage of GDP across all products except fuel and lubricants, for which we report negative values significant at $1 \%$ level. In table 2 , we report the results of our regressions for primary and processed products of food and beverages, industrial supplies and fuel and lubricants. We report positive values for manufacturing as a percentage of GDP, significant at $1 \%$ level, across both primary and processed products in food and beverages and industrial supplies. However, the relationship between manufacturing as a percentage of GDP and import values is negative and significant at $1 \%$ level for primary products of fuel and

Business Review: (2017) 12(1):20-49 
A. Nakhoda, F. Pasha

Table 2: OLS regressions of manufacturing and services on import value without control variables for listed product types within the broad economic categories

\begin{tabular}{l|llllll}
\hline \multirow{2}{*}{ Import Value } & 1 & 2 & 3 & 4 & 5 & 6 \\
\hline M\%of GDP $(\ln )$ & FB:Pri & FB:Pro & IS:Pri & IS:Pro & FL:Pri & FL:Pro \\
& $1.03^{* * *}$ & $2.36^{* * *}$ & $1.06^{* * *}$ & $2.30^{* * *}$ & $-2.88^{* * *}$ & 0.25 \\
S\%of GDP $(\ln )$ & -0.18 & $2.35^{* * *}$ & $0.69^{* * *}$ & $2.25^{* * *}$ & $-8.49^{* * *}$ & $-1.67^{* * *}$ \\
& $(0.306)$ & $(0.397)$ & $(0.245)$ & $(0.282)$ & $(0.958)$ & $(0.597)$ \\
Constant & $10.9^{* * *}$ & $-3.3^{* *}$ & $8.1^{* * *}$ & -1.0 & $56.3^{* * *}$ & $19^{* * *}$ \\
& $(1.163)$ & $(1.644)$ & $(0.987)$ & $(1.132)$ & $(4.505)$ & $(2.801)$ \\
Obs & 1,222 & 1,057 & 1,722 & 1,986 & 248 & 710 \\
$R^{2}$ & 0.034 & 0.146 & 0.057 & 0.197 & 0.293 & 0.017 \\
\hline
\end{tabular}

Note: Robust standard errors in parentheses.

*** $p<0.01, * * p<0.05,{ }^{*} p<0.1$

lubricants but negative and insignificant for processed products of fuel and lubricants. The value of the coefficient for services as a percentage of GDP is positive and significant at $1 \%$ level for processed products in food and beverages, primary and processed products in industrial supplies but negative and significant at $1 \%$ level for primary and processed products in fuel and lubricants. In addition, we observe a negative but insignificant value for the coefficient of services as a percentage of GDP for primary products in food and beverages. The results suggest that Pakistan is likely to import all products except fuel and lubricants, both primary and processed, from countries with higher value added in the manufacturing sector as a percentage of GDP. Similarly, services as a percentage of GDP is likely to positively influence import value into Pakistan for all products except primary and processed products in fuel and lubricants.

In table 3, we include all the control variables defined in equation (1). We find that manufacturing as a percentage of GDP influences the import value similar to table 1 . The only difference between table 1 and table 3 is that the direction of the sign for fuel and lubricants changes from negative in table 1 to positive, at $10 \%$ level of significance, in table 3 .

On the other hand, the coefficients for services as a percentage of GDP for industrial supplies changes from positive in table 1 to negative in table 3 . The coefficient is now insignificant for food and beverages but negative and significant at $1 \%$ level for industrial supplies. The coefficients are now insignificant for food and beverages, capital goods and consumer goods, while the coefficient for transportation equipment is positive and significant at $5 \%$ level. Inclusion of country characteristics changes the sign of the contribution of the services sector as a percentage of GDP as reported in table 1. In other words, we expect Pakistan to import from countries with a smaller services sector given country characteristics such as GDP per capita, remoteness and the gravity between Pakistan and its trading partner. We find positive relationship, significant at $1 \%$ level, for GDP per capita, percentage of exports to lower middle income countries, border with Pakistan and common official language across all products. We find negative coefficients, significant at $1 \%$ level, for remoteness and exports as a percentage of GDP. The former suggests that Pakistan is likely to import 
from countries which are located closer to the core and the latter suggests that Pakistan is less likely to import from countries that produce output mainly for the export market. ${ }^{15}$

Weighted average tariffs are positive and significant at $5 \%$ for the imports of capital goods and insignificant for all other goods. This suggests that trade is unlikely to be influenced by lowering of import tariffs across all products. The direction of the sign of the coefficients for the distance between Pakistan and its trading partners, border with Pakistan and common official language for all products are as expected. We do not find any significance for the distance variable for food and beverages. The direction of the sign of the coefficient for colonial link and for common colonizer post 1945 is negative and significant at $1 \%$ level and $10 \%$ level respectively for fuel and lubricants. This suggests that Pakistan is less likely to import fuel and lubricants either from the UK or from countries that were part of the British Empire post 1945. We also observe a negative impact, significant at $10 \%$ level, for the coefficient for capital goods, suggesting that Pakistan is less likely to import capital goods from countries that were part of the British Empire post 1945.

In table 4, we report the results for the import values into Pakistan in primary products as well as processed products of food and beverages, industrial supplies and fuel and lubricants. We report positive coefficients for manufacturing as a percentage of GDP that are significant at 1\% level for all our regressions except for primary products in fuel and lubricants, for which the coefficient is negative and significant at $1 \%$ level. This suggests that conversion of imported primary products into processed products are likely to occur in different countries. We also report a negative coefficient, significant at $1 \%$ level, for services as a percentage of GDP for primary products in fuel and lubricants, at $5 \%$ level for processed fuel and lubricants and processed industrial supplies and at 10\% level for primary food and beverages.

Interestingly, we find the coefficients on percentage share of exports to LMIC, common colonizer post 1945 and colonial link to be negatively correlated with import values for primary products of fuel and lubricants, while the coefficient for remoteness is positive. This suggests that imports in primary products of fuel and lubricants are likely to be from countries that mainly export to countries other than lower middle income countries, are not likely to have been colonized by Britain post 1945 nor imported from the UK. In addition, the imports of primary products of fuel and lubricants is likely to be from more remote countries that are located further away from the largest trading countries. This is as expected, as majority of the oil exporting countries are likely to export to developed countries and several of them have not been colonized by Britain.

We find that imports of fuel and lubricants, particularly primary products, do not follow the same trend as imports of other products. The imports of primary products of fuel and lubricants are less dependent upon the size of the manufacturing sector relative to GDP in the trading partner. The extraction of fuel and lubricants may require the least value addition through the manufacturing sector in the trading partner. As the processed products of fuel and

\footnotetext{
15 Larger economies are more likely to produce output for the domestic market rather than the export market.
}

Business Review: (2017) 12(1):20-49 
lubricants are imported from countries with larger manufacturing sectors relative to GDP, which are likely to be different from the countries it imports primary products of fuel and lubricants, it is likely that Pakistan can benefit the most from imports of primary products in fuel and lubricants by converting them into processed goods domestically.

In tables 5 and 6 , we report the results of the GLS regressions. These results are similar to that reported in tables 3 and 4 . In table 5 , we find a positive impact of the size of the manufacturing sector relative to GDP, with significance level of at least $5 \%$, across all categories. We find that value added in services as a percentage of GDP influences the import flow positively into Pakistan for capital goods and consumer goods but not for transportation equipment. On the other hand, the size of services relative to GDP has a negative impact on the imports of industrial supplies and fuel and lubricants. This suggests that complementary service activities may not be important for industrial supplies and fuels and lubricants. In table 6 , we find a negative influence, albeit insignificant, of the size of the manufacturing sector on the imports of primary products in fuel and lubricants. ${ }^{16}$

However, services as a percentage of GDP is negative for primary and processed products of fuels and lubricants at $1 \%$ and $10 \%$ level of significance respectively. Therefore, imports into Pakistan are likely to be dependent upon the size of the manufacturing sector relative to GDP but less dependent upon the size of the services sector relative to GDP in the trading partner. Even though, the results may differ from that reported for the OLS regressions in tables 3 and 4 , the results in tables 5 and 6 reinforce the role of the size of the manufacturing sector relative to GDP.

In tables 7 and 8 , we report the standardized coefficients for the OLS regressions on the import value. The standardized coefficients determine the impact on the import value into Pakistan of one standard deviation increase in the independent variables. It is important to note that the value added as a percentage of GDP by the manufacturing sector ranks amongst the top two variables for each category except fuel and lubricants. The impact of value added by services sector as a percentage of GDP on import value is not as high as that of the manufacturing sector, except for fuel and lubricants. In table 8 , we find that the imports of primary products of food and beverages and fuel and lubricants are less responsive to the changes in the value added by the manufacturing sector than the imports of processed products within the same categories. This suggests that Pakistan is more likely to import processed products from countries with larger manufacturing sectors relative to GDP than primary products.

This is consistent with the expectation that countries with a larger manufacturing sector relative to GDP are likely to have greater comparative advantage in the production of manufactured goods. Therefore, Pakistan will import higher value of processed products as it becomes more dependent upon the imports of

\footnotetext{
16 Although insignificant, the direction of the sign of the coefficient is different from that of all other products listed. This gets the point across that primary products of fuels and lubricants are impacted differently by the size of the manufacturing sector relative to GDP in the trading partners compared to the other products. We obtain the same trend in the OLS regression.
} 
trading partners with a larger manufacturing sector relative to their GDP. If we are to consider the trend of imports of primary products in fuel and lubricants, it suggests that Pakistan is likely to import such products from countries that are not industrialized. On the other hand, Pakistan is likely to import primary products of food and beverages and industrial supplies from countries that have industrialized their economy. The same can be said for the processed products imported into Pakistan in food and beverages, industrial supplies and fuel and lubricants.

Our theoretical discussion above suggests that the import from trading partners with a larger manufacturing sector relative to GDP may lower the competitiveness of the processed products produced in Pakistan. Industrialized countries are likely to more effectively convert primary products into processed products and the imports into Pakistan are likely to impact the manufacturing sector creating a vicious cycle. As imports are likely to be sourced from industrialized countries, it is imperative that Pakistan considers investment to complement production in such countries through vertical specialization as it increases the importance of imports of primary products into Pakistan. 


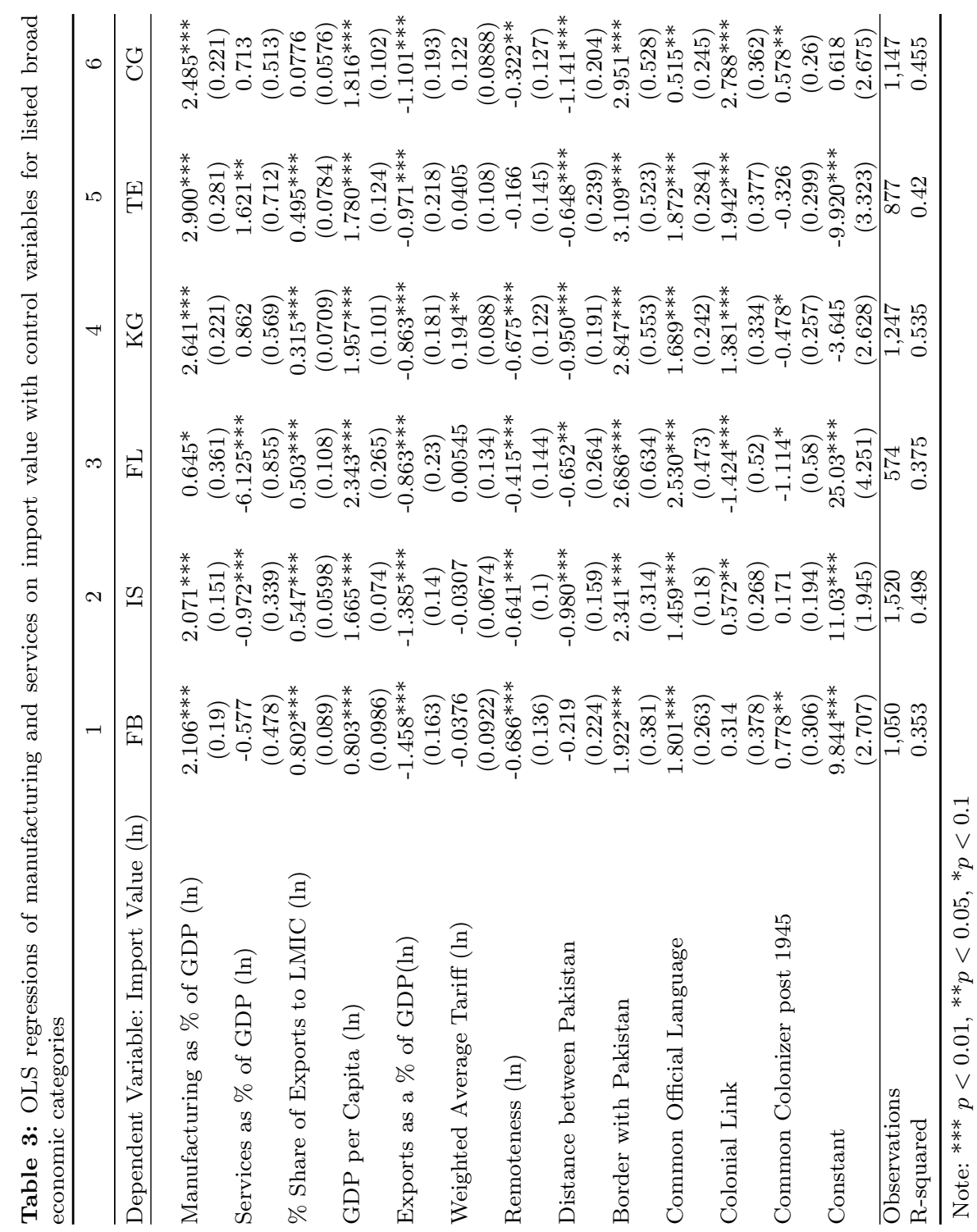




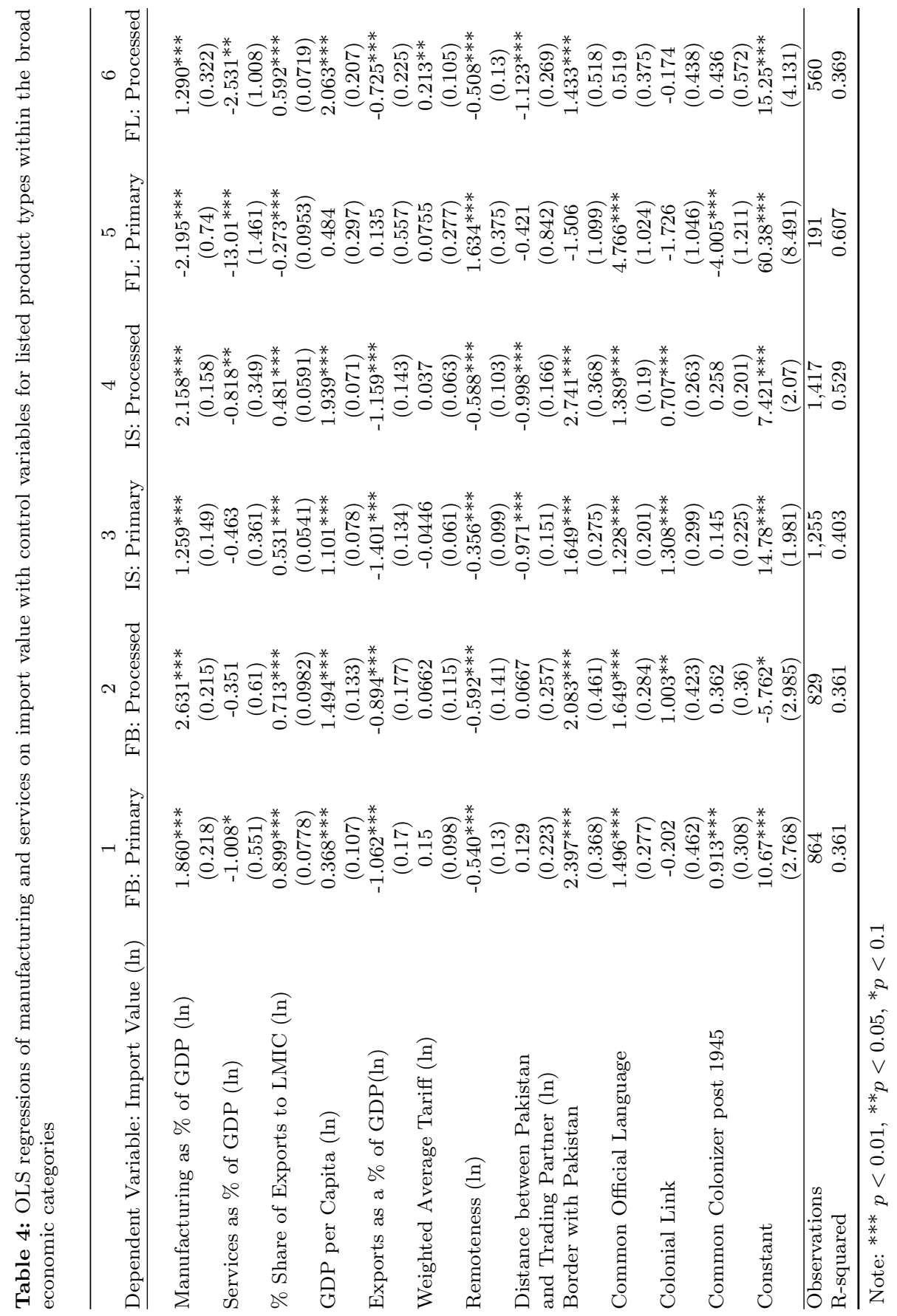

Business Review: (2017) 12(1):20-49 


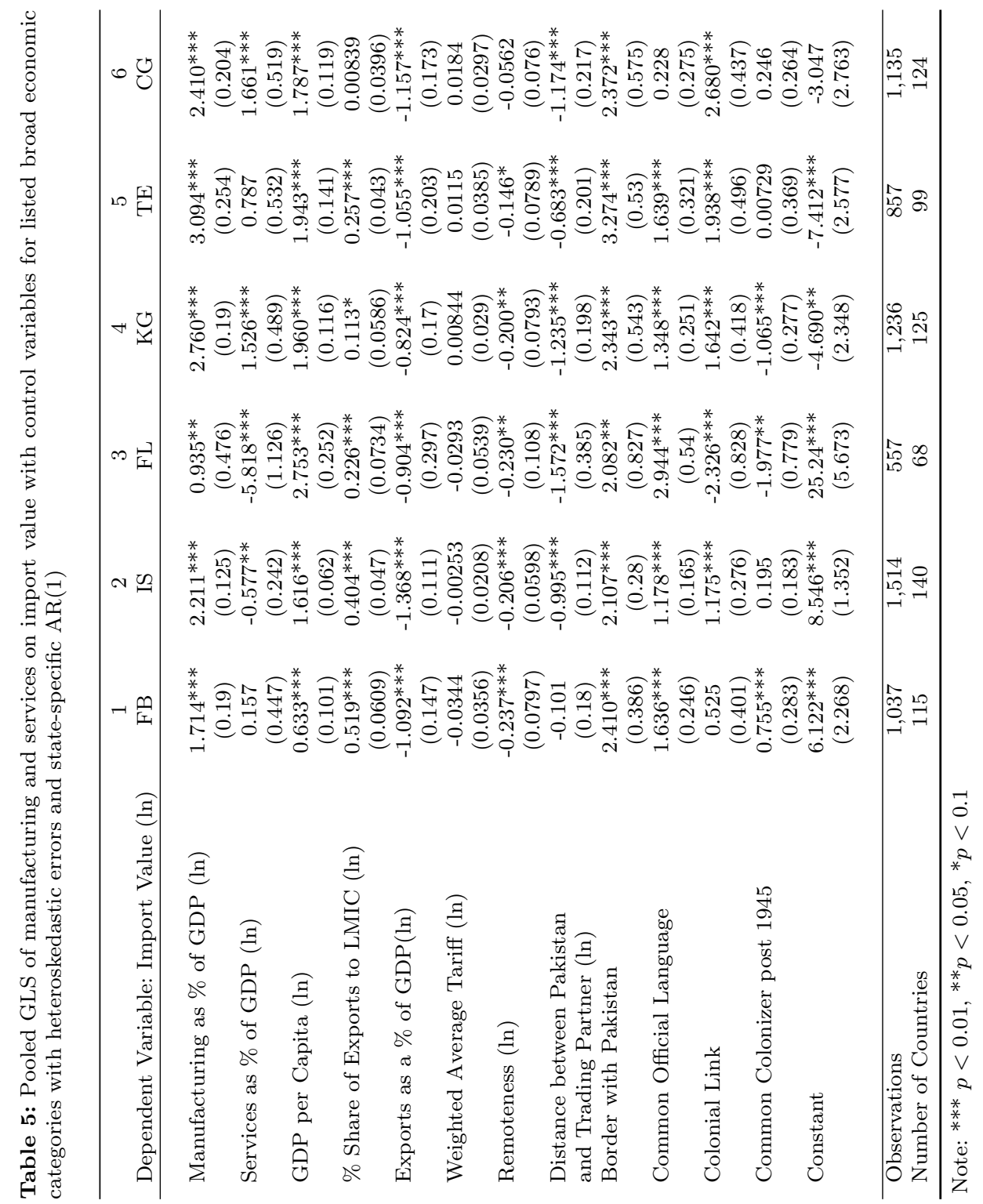




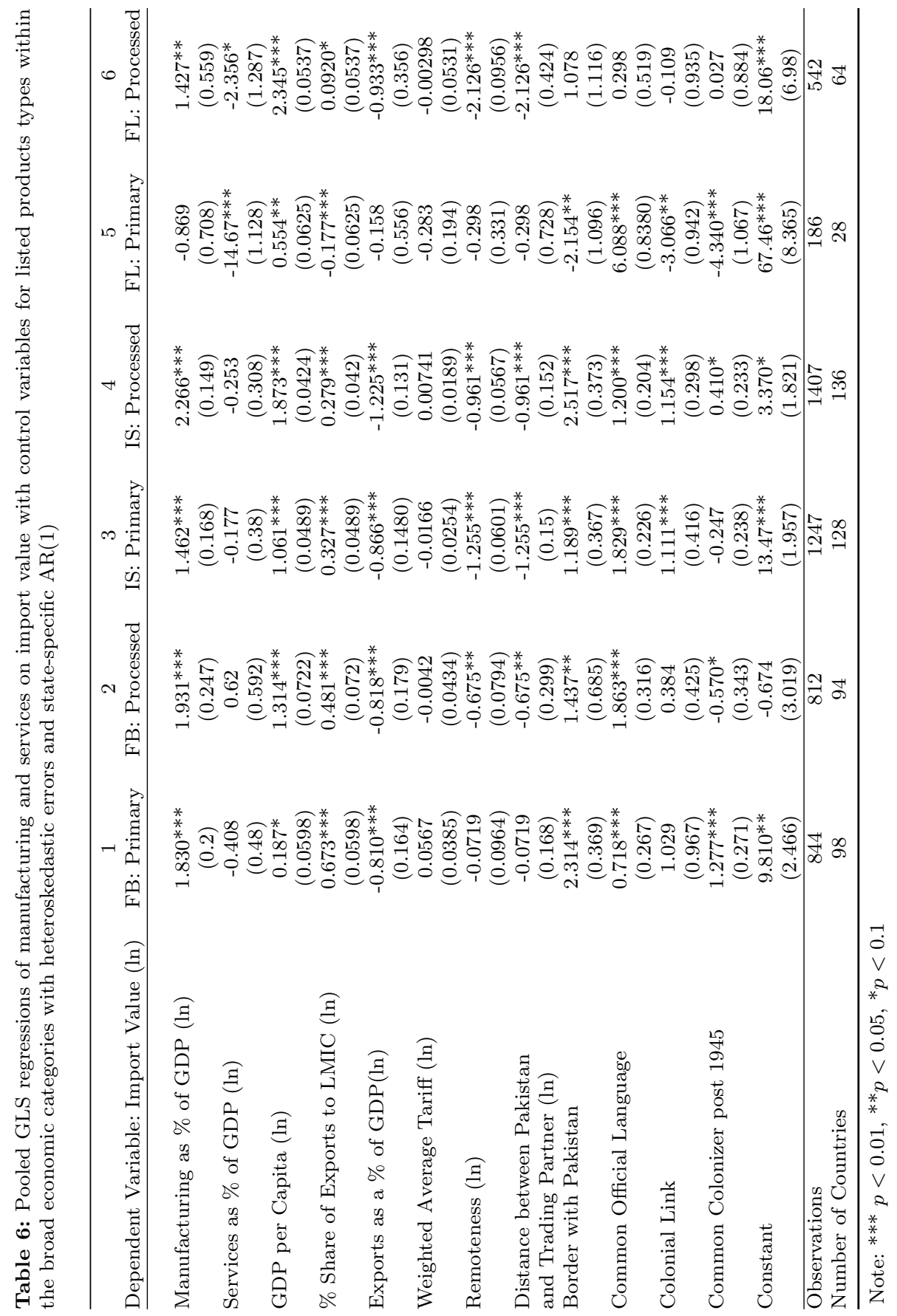

Business Review: (2017) 12(1):20-49 


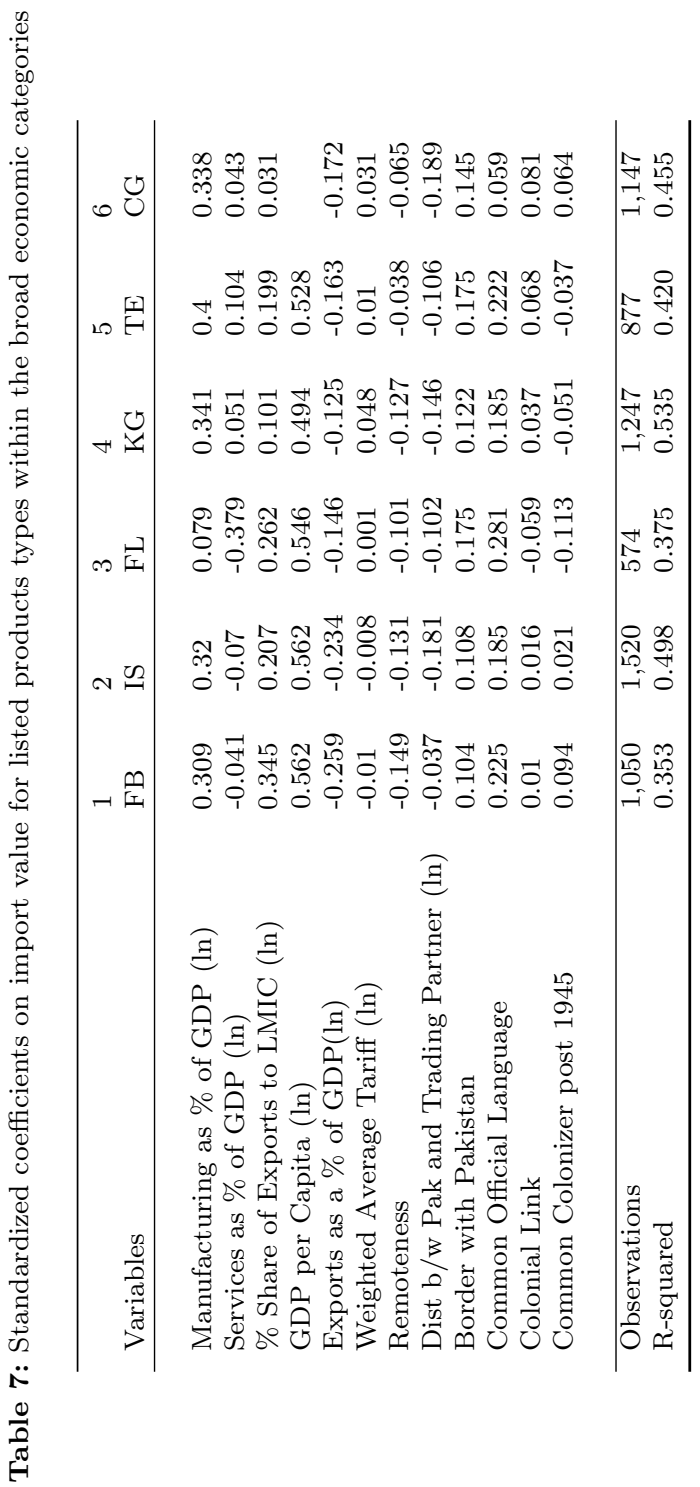




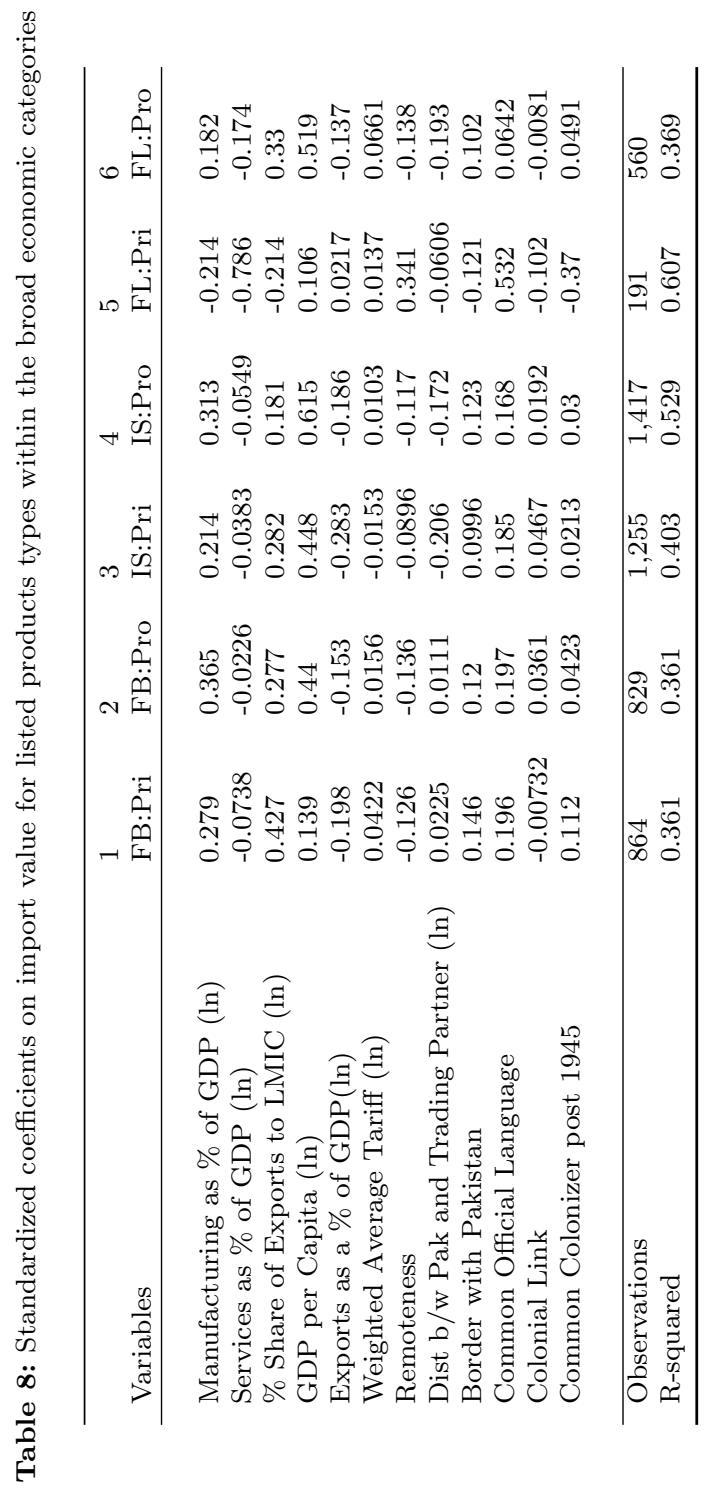

Business Review: (2017) 12(1):20-49 


\section{Conclusion}

In this paper, we have determined the relationship between imports into Pakistan and the size of the manufacturing sector relative to GDP. We find that imports of all goods are likely from countries with larger manufacturing sectors relative to GDP. However, when we classify the goods into primary and processed products, we find positive relationships between the size of the manufacturing sector relative to GDP in trading partners and the imports of primary as well as processed products of food and beverages and industrial supplies. In addition, we include a control on the size of the services sector relative to GDP. There is mainly a negative impact, with varying levels of significance, of the size of the services sector relative to GDP on imports of primary and processed products of food and beverages, industrial supplies and fuel and lubricants. Imports into Pakistan are more likely to be influenced by the size of the manufacturing sector relative to GDP rather than the size of the services sector relative to GDP.

In essence, our paper suggests that Pakistan is likely to be dependent upon imports from industrialized countries as these countries are likely to have a comparative advantage in production due to their greater efficiencies. If the policymakers desire to revive industrial growth and manufacturing activity in Pakistan, it is imperative that policies are introduced that attract investments in the manufacturing sector to produce goods which can be incorporated into the global production network. For instance, Pakistan imports primary products of fuel and lubricants from countries that do not have a large manufacturing sector relative to GDP. As value addition in the primary products is likely to be lower than in processed products, the imports of primary products in fuel and lubricants and domestic conversion into processed products should be a viable option. We did observe a surge in the imports of primary products of fuel and lubricants in 2004 and 2005.

Similarly, Pakistani policymakers must consider integration into the global production networks and value chains such that primary products of food and beverages and of industrial supplies can be converted to processed products domestically. Unfortunately, in our estimations we report a stronger impact of the manufacturing sector relative to GDP on the imports of processed products in food and beverages and industrial supplies than in the imports of primary products of the aforementioned categories. The revival of the manufacturing sector in Pakistan may be possible if the focus is on the labor-intensive industrial processes, such that the economy can benefit from vertical specialization. Viable trade policies need to be introduced in order to tackle the growth in import dependency on industrialized trading partners and reinvigorate the domestic manufacturing sector.

\section{References}

Amiti M, Konings J (2007) Trade liberalization, intermediate inputs and productivity: Evidence from indonesia. The American Economic Review 1611-1638 
Choudhary A, Pasha F (2015) The quest for dividends from structural change. sbp research bulletin, 11(1): 87-94.

Dornbusch R, Fischer S, Samuelson PA (1977) Comparative advantage, trade, and payments in a ricardian model with a continuum of goods. The American Economic Review 67(5):823839

Eaton J, Kortum S (2001) Technology, trade, and growth: A unified framework. European economic review 45(4):742-755

Goldberg P, Khandelwal A, Pavcnik N, Topalova P (2009) Trade liberalization and new imported inputs. The American Economic Review 99(2):494-500

Hamid N, Khan M (2015) Pakistan: A case of premature deindustrialization? The Lahore Journal of Economics 20:107

Hausmann R, Hwang J, Rodrik D (2007) What you export matters. Journal of economic growth 12(1):1-25

Hummels D, Klenow PJ (2005) The variety and quality of a nation's exports. The American Economic Review 95(3):704-723

Hummels D, Ishii J, Yi KM (2001) The nature and growth of vertical specialization in world trade. Journal of international Economics 54(1):75-96

Krugman P, Lawrence R (1993) Trade, jobs, and wages. no. w4478. national bureau of economic research

Krugman P, Venables AJ (1995) Globalization and the inequality of nations. The quarterly journal of economics 110(4):857-880

Kugler M, Verhoogen E (2009) Plants and imported inputs: New facts and an interpretation. The American Economic Review 99(2):501-507

Rasiah R, Nazeer N (2015) The state of manufacturing in pakistan. The Lahore Journal of Economics 20:205

Rodrik D (2016) Premature deindustrialization. Journal of Economic Growth 21(1):1-33

Rowthorn RE, Ramaswamy R (1997) Deindustrialization: causes and implications. staff studies for the world economic outlook, 1997, 61 .

\section{Appendix}

Appendix A

Business Review: (2017) 12(1):20-49 
A. Nakhoda, F. Pasha

Table A1: List and description of variables

\begin{tabular}{|c|c|c|}
\hline Variable & Source & Note \\
\hline Import Value & UN COMTRADE & \\
\hline Manufacturing as $\%$ of GDP & WDI & \\
\hline Services as $\%$ of GDP & WDI & \\
\hline$\%$ Share of Exports to LMIC & UN COMTRADE & $\begin{array}{l}\text { Exports from trading partner } \\
\text { to lower and middle income } \\
\text { countries as a proportion of } \\
\text { total global exports from } \\
\text { trading partner }\end{array}$ \\
\hline GDP per Capita & WDI & $\begin{array}{l}\text { PPP, constant } \\
\text { international dollars }\end{array}$ \\
\hline Exports as a \% of GDP & WDI & \\
\hline Weighted Average Tariff & WITS & \\
\hline Remoteness & UN COMTRADE & $\begin{array}{l}\text { Calculated using Notes on } \\
\text { UNDP Least Developed } \\
\text { Country Graduation Criteria } \\
\text { by Zhou }\end{array}$ \\
\hline $\begin{array}{l}\text { Distance between Pakistan } \\
\text { and trading partner }\end{array}$ & CEPII & \\
\hline Border with Pakistan & CEPII & \\
\hline Common Official Language & CEPII & \\
\hline Colonial Link & CEPII & \\
\hline Common Colonizer post 1945 & CEPII & \\
\hline
\end{tabular}

Appendix B

Table A2: Broad economic categories and two-digit products

\begin{tabular}{|l|l|}
\hline Broad Economic Category (Top-Level) & Product (Two-Digit) \\
\hline Food and Beverages (1), (FB) & Primary (11), Processed (12) \\
\hline Industrial Supplies (2), (IS) & Primary (21), Processed (22) \\
\hline Fuels and Lubricants (3), (FL) & Primary (31), Processed (32) \\
\hline $\begin{array}{l}\text { Capital goods (except transportation } \\
\text { equipment) (4), (KG) }\end{array}$ & Capital goods, parts and accessories \\
\hline Transport Equipment (5), (TE) & $\begin{array}{l}\text { Passenger motor cars, other, parts and } \\
\text { accessories }\end{array}$ \\
\hline $\begin{array}{l}\text { Consumer goods not elsewhere classified (6), } \\
\text { (CG) }\end{array}$ & Durable, Semi-durable, non-durable \\
\hline
\end{tabular}




\section{Appendix C}

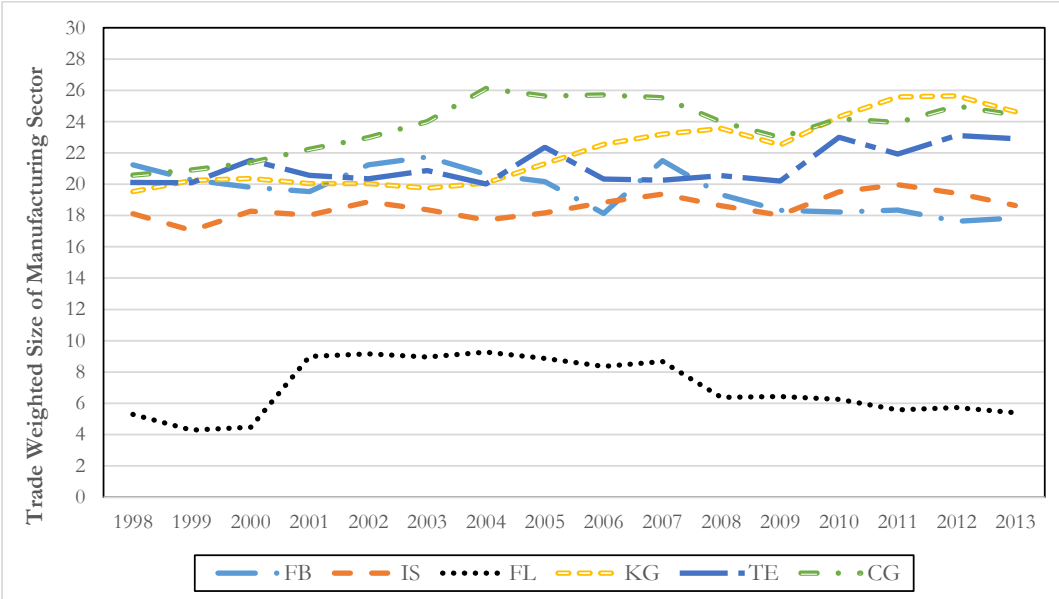

Fig A1: Size of the manufacturing sector in the source country weighted by imports of respective goods from the source country into Pakistan

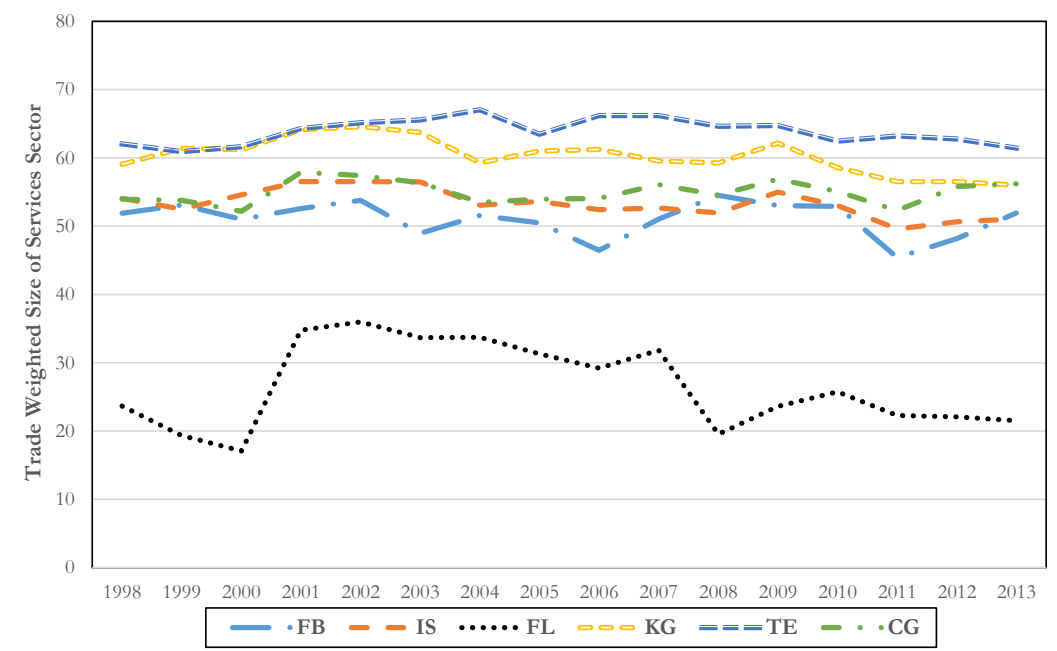

Fig A2: Size of the services sector in the source country weighted by imports of respective goods from source country into Pakistan

Business Review: (2017) 12(1):20-49 